\title{
Feed potentials of Saccharomyces cerevisiae biomass cultivated in palm oil and cassava mill effluents
}

\begin{abstract}
Saccharomyces cerevisiae biomass is one of the microbes of food safety. In animals, Saccharomyces cerevisiae in their diets are known to play several vital roles including prevention of diarrhea and mortality, boosting of immune system, performance, milk production, fiber degradation and nutrient digestability, adsorption of toxic metal such as cadmium, stabilization of rumen $\mathrm{pH}$ and microorganisms. Saccharomyces cerevisiae have been widely cultured in several waste feedstocks' including cassava and palm oil mill effluents. Nigeria is the largest and fifth leading producer of cassava and oil palm, respectively in the world. During processing, large volume of wastewater are generated as effluents. These wastewaters are known to cause severe environmental impacts including odour pollution and bareness in receiving soil. In aquatic ecosystem both effluents could lead to eutrophication and increased acidity content. Specifically, cassava mill effluent could cause toxicity on fisheries, vegetation, ruminant animals. This study reviews the potentials of Saccharomyces cerevisiae biomass cultured in oil palm and cassava processing effluents for utilization in animal feed. The study showed that biomass cultured in both effluents contain high total essential amino acids $(>40 \mathrm{~g} / 100 \mathrm{~g})$ compare to Food and Agricultural Organization/World Health Organization standard values $(33.9 \mathrm{~g} / 100 \mathrm{~g})$ for feed. Based on proximate composition the results are also promising especially with protein content which is higher than $17 \%$. But the yield was low (approximately $4 \mathrm{~g} / \mathrm{l}$ ) in both effluents. In cassava mill effluents, palm oil, heat and fermentation aid in the reduction of cyanide content. Hence, there is the need for research to focus on manipulation of the environmental parameters such as $\mathrm{pH}$ and temperature to increase yield, nutrient content (viz: amino acids and proximate compositions). This could aid in minimizing the environmental effects associated with cassava and oil palm processing wastewater.
\end{abstract}

Keywords: animal feed, amino acid, cassava, biotechnology advances, effluents micro organisms, oil palm, yeast
Volume 6 Issue 5 - 2018

\author{
Sylvester Chibueze Izah \\ Department of Biological Sciences, Faculty of Science, Niger \\ Delta University, Nigeria
}

\begin{abstract}
Correspondence: Sylvester Chibueze Izah, Department of Biological Sciences, Faculty of Science, Niger Delta University, Wilberforce Island, Bayelsa State, Nigeria, Tel +2347030192466, Email chevestizah@gmail.com
\end{abstract}

Received: June 10, 2018 | Published: October 19, 2018

\section{Introduction}

Oil palm and cassava are major crops that are used for the productions of several products. Unlike cassava, oil palm which belongs to the palmae family is an oil crop that is used to produce palm kernel oil and crude palm oil. Of these two types of oil, crude palm oil is the most utilized oil. On global scale, palm oil is one of the most resourceful. As such,it has found applications is several sectors including biodiesel production, soup, soap, lubrications, base for polish, pharmaceutical industry, confectionary, animal feed among others. ${ }^{1-8}$ On the other hands, cassava is a typical dietary carbohydrate crops with energy content of about $720 \times 10^{12} \mathrm{KJ} /$ day. ${ }^{9}$ Cassava have been ranked as fourth cheap source of dietary carbohydrate after rice, sugarcane and maize, and $5^{\text {th }}$ among starch crops on global scale. ${ }^{9}$ In Nigeria, three major variety of oil palm exists including Dura and Pisifera and Tenera (an hybrid produced from Dura and Pisifera through research and development, and its characterized by a thinshelled fruit and improved partition of dry matter). ${ }^{6}$ The Tenera produce the highest volume of crude palm oil. According to Ohimain et al. ${ }^{6}$, about $80 \%$ of oil palm plantation in Nigeria is dominated by Dura and Pisifera varieties that are mostly found in the wild. While the rest $20 \%$ is covered by Tenera varieties that are mostly found in plantations. Oil palm sector including its cultivation and processing in Nigeria are dominated by smallholders et al. ${ }^{10-12}$ Furthermore, several varieties of cassava are found in Nigeria. Most of the cassava varieties were discovered through research and development especially between 1999-2010. Nigeria is the leading cassava producing nation in the world accounting for over $20 \%$ of global production. ${ }^{13-24}$. Beside Nigeria, cassava is produced in several other countries including Thailand, Brazil, Indonesia, Ghana, Congo Democratic Republic, Vietnam, Angola, and Mozambique among others. In addition, a significant portion of global cassava production is carried out in Africa. On global scale, Nigeria account for about $1.5 \%$ of total oil palm production being the fifth largest producing nation. $3,4,25$ Typically Indonesia, Malaysia, Thailand and Colombia are the first four largest oil palm producing nation. The production of oil palm has not witnessed any massive growth within the last decades despite the efforts of the Nigerian government to boost agricultural sector. The processing of fresh fruit bunch of oil palm into crude palm oil requires larges volume of water which often end up as waste water as previously reported in literatures..$^{26-36}$ In a similar note, the processing of cassava into gari generates larges waste water during dewatering stage. Ohimain et al. ${ }^{37}$ estimated that about $16 \%$ of total cassava tuber end up as waste water. In developing country like Nigeria the waste water from oil palm and cassava processing are underutilized and they are seldom treated before discharging into the ecosystem. Studies have suggested that most of effluents generated by both food processors are discharged into the soil, which then percolates and/ or drain into the nearby pits, surface water etc. ${ }^{23,24}$ The effluents have the tendency to alter the characteristics of the receiving soil, which 
then emits offensive odours. Odours associated with cassava and oil palm processing can be perceived from some distance up to 100 feet depending on the scale of processing and effluent discharging density as well as the duration of effluents degradation by indigenous microbes. Specifically cassava mill effluents have been reported by authors to lower the density of soil microorganisms. ${ }^{38,39}$ On aquatic ecosystem, studies have indicated that they could cause changes with regard to histopathological, haematological, enzymes, behavioural response, mortality etc in fisheries. ${ }^{21,40,41}$ In the soil, cassava mill effluents can also hinder germination, proper growth and productivity of some plant species. ${ }^{42-45}$ Toxicity of cassava mill effluents to some domestic animals have been documented in literatures as well. ${ }^{21}$ Due to the toxicity of cassava and oil palm processing effluents to the ecosystems, studies have demonstrated the potentials for utilization through biotechnological advancement. To this regard both effluents have been studied for enzymes production, biosurfactants, organic acids, bioenergy (bio-hydrogen, biogas, bioethanol, bioelectricity), cultivation of Saccharomyces cerevisiae biomass. Typically, Broadway et $a l .{ }^{46}$ reported that yeast and yeast-based products is essential during birth, weaning, early lactation, and enhancement of animal health and metabolism while decreasing morbidity, thereby enhancing profitability of these animals. Therefore, this study focused on feed potentials of these food processing effluents for possible utilization in animal feeds.

\section{Biomass generations during the treatment of palm oil and cassava mill effluents with Saccharomyces cerevisiae}

Oil palm and cassava mill effluents contain total solids, total suspended solid, acidic $\mathrm{pH}$, high chemical oxygen demand, total dissolved solid, heavy metals among several other physicochemical parameters. Some of the physicochemical parameters of the effluents often exceed the limits for all categories of effluents to be discharged into the Nigerian ecosystem as recommended by Federal Environmental Protection Agency (1991). During the use of the effluents through biotechnological advancement some of the physiochemical parameters are lowered. For instance, Iwuagwu \& Ugwuanyi ${ }^{47}$ reported that Saccharomyces,Pichia and Candida species have the tendency to reduce chemical oxygen demand and $\mathrm{pH}$ (tending toward alkalinity) of oil palm processing mill effluents. In a similar study Izah et al. ${ }^{16}$ reported that Saccharomyces cerevisiaecould reduce the content of cassava mill effluents by $37.62 \%, 22.96 \%, 29.63 \%$, $20.49 \%, 21.44 \%, 1.70 \%, 53.48 \%, 68.00 \%, 100 \%$, and $74.48 \%$ for $\mathrm{pH}$, conductivity, dissolved oxygen, total dissolved solid, salinity, sulphate, nitrate, phosphate, and chemical oxygen demand levels respectively, and an elevation of turbidity by $17.17 \%$. Izah et al. ${ }^{17,20}$ also reported that Saccharomyces cerevisiae have the tendency to uptake heavy metals in cassava mill effluents through biosorption. During the treatment of cassava and palm oil mill effluents by microorganisms sludge are generated. The sludge/biomass generated at the bottoms of treatment chamber have been washed, dried and estimated in literature. For instance, Iwuagwu \& Ugwuanyi ${ }^{47}$ reported maximum yield of $4.42 \mathrm{~g} / \mathrm{L}$ for Saccharomyces species used for the treatment of cassava mill effluents. Izah $^{23}$ also reported a yield of $3.93 \mathrm{~g} / \mathrm{L}$ for Saccharomyces cerevisiaeduring the treatment of cassava mill effluents. Probably due to the variation in nutrients composition of the effluents yield could be different. Furthermore, environmental factors such as temperature and $\mathrm{pH}$ could also influence the yield and quality of the biomass as well. Unlike oil palm, cassava contain cyanide which is one the constituents that accounts for its toxicity. During treatment, studies have shown that Saccharomyces cerevisiae has the tendency to reduce the concentration of cyanide in cassava mill effluents and the associated biomass. ${ }^{18}$ Typically cyanide concentration is influenced by heat treatment, additives such as palm oil and fermentation by several microbes such as Saccharomyces and Lactobacillus species. ${ }^{18,23}$

\section{Feed potentials of Saccharomyces cerevisiae}

Saccharomyces cerevisiae is one of the main species of yeast that is widely utilized in several industrial sectors..$^{21,48}$ The choice of Saccharomyces cerevisiae is an industrial setting could be due to their ability to breakdown sugars (i.e. glucose, maltose) to form ethanol and carbon dioxide. ${ }^{49}$ Saccharomyces cerevisiae have been widely used for fermentation of different substrates. Saccharomyces cerevisiae is an essential microorganism that has been considered useful in animal feed to improve production and health status. ${ }^{50}$ Saccharomyces cerevisiae which are used as probiotics are nutritionally high in enzymes, fatty acids, vitamin B complex, unknown growth factors and amino acids (more than $40 \%$ of total dry matter) (Sontakke, 2012). Saccharomyces cerevisiae cultured in cassava mill effluents have been reported to contain essential heavy metals, ${ }^{20}$ low cyanide and cations, ${ }^{18}$ proximate composition and amino acids. ${ }^{19}$ Furthermore, proximate composition, amino acids, heavy metals, cations, etc have been reported in brewer's yeast. ${ }^{51}$ Table $1 \& 2$ presents the proximate composition and amino acids profile of Saccharomyces cerevisiae biomass cultured in cassava and palm oil mill effluents respectively. Studies have shown that Saccharomyces cerevisiae contain crude protein, lipid, fibre and carbohydrate. Typically cassava is known as a carbohydrate crops with low protein content. But during fermentation of carbohydrate substrate with Saccharomyces cerevisiae the protein content is enhanced. For instance, Onyeulor and Nwaehiri ${ }^{52}$ reported that Saccharomyces cerevisiae (BY 4743) could enhance the protein content of potato peels through fermentation. Aruna et al. ${ }^{53}$ reported protein enrichment of yam peels by fermentation using Saccharomyces cerevisiae (BY4743). Based on Table 2, the amino acids of Saccharomyces cerevisiae biomass from both effluents in comparison to Food and Agricultural Organization/World Health Organization limits for single cell protein meant for animal feed revealed that the values of the essential amino acids including isoleucine, leucine, tryptophan, histidine and combination of phenylalanine, tyrosine etc were superior and/ or comparable to recommended limit for single cell protein. On the other hand the total non-essential amino acids were lower compared to Food and Agricultural Organization/World Health Organization limits ${ }^{54}$ (Table 2), a trend that have been previously reported by Izah et al. ${ }^{19}$ in Saccharomyces cerevisiae biomass culture in cassava mill effluents and Iwuagwu and Ugwuanyi ${ }^{47}$ in Saccharomyces species biomass cultured in palm oil mill effluents. The values of essential amino acids suggest that they can be used for animal feed if every other nutrient constituent are adequate. Variations exist between the proximate constituents and amino acid of Saccharomyces species biomass cultured in both cassava and palm oil mill effluents. The different could be due to changes in constituents of the waste water as well as environmental condition (mainly temperature and $\mathrm{pH}$ ) of effluents they were cultured. Other internal factors could also affect the nutrient composition. In a similar study, Ogbonda et al. ${ }^{55}$ reported that temperature and $\mathrm{pH}$ influence the yield/productivity, proximate composition and amino acid of Spirulina species biomass.

Table I Proximate composition of the Saccharomyces cerevisiaebiomass 
cultured in palm oil and cassava mill effluents

\begin{tabular}{lll}
\hline Proximate composition & Cassava mill effluents ${ }^{19}$ & Palm oil mill effluents $^{47}$ \\
\hline \% Crude protein & 17.01 & 27 \\
\% Crude fat/ lipid & 12.57 & 0.83 \\
\% Crude fibre & 2.71 & 4.7 \\
\% Moisture & 7.12 & - \\
\% Ash & 7.34 & 6.12 \\
\% Carbohydrate & 56.4 & 35.45 \\
Energy (kcal/l00g) & 407.13 & - \\
\hline
\end{tabular}

Table 2 Amino acid profile of S. cerevisiae cultured in palm oil and cassava mill effluents expressed as $\mathrm{g} / \mathrm{I00 \textrm {g }}$ of protein

\begin{tabular}{|c|c|c|c|}
\hline Amino acids & Cassava mill effluents ${ }^{19}$ & Palm oil mill effluents ${ }^{47}$ & FAO/WHO ${ }^{54}$ \\
\hline Phe + Tyr & 6.09 & 8.68 & 6.3 \\
\hline Tyrosine & 2.24 & -- & - \\
\hline Phenylalanine & 3.85 & -- & - \\
\hline Isoleucine & 9.01 & 3.09 & 2.8 \\
\hline Leucine & 7.02 & 10.25 & 6.6 \\
\hline Lysine & 2.95 & 6.01 & 5.8 \\
\hline Methionine & 1.46 & 5.05 & 2.5 \\
\hline Tryptophan & 5.09 & 6.76 & I.I \\
\hline Valine & 2.57 & 7.13 & 3.5 \\
\hline Threonine & 2.06 & 3.57 & 3.4 \\
\hline Histidine & 4.63 & 1.91 & 1.9 \\
\hline Total essential & 40.88 & 52.45 & 33.9 \\
\hline Proline & 2.28 & 1.87 & 10.7 \\
\hline Arginine & - & 3.85 & 5.2 \\
\hline Alanine & 2.01 & 2.97 & 6.1 \\
\hline Glutamine & - & 2.95 & - \\
\hline Aspartic acid & 5.57 & 2.6 & 7.7 \\
\hline Asparagine & 2.01 & 8.54 & - \\
\hline Glutamic acid & 4.15 & 11.1 & 14.7 \\
\hline Glycine & 2.52 & 3.71 & 2.2 \\
\hline Serine & 2.41 & 3.57 & 7.7 \\
\hline Trimethylserine & - & 3.53 & - \\
\hline Cysteine & 0.45 & - & - \\
\hline Pyrrolysine & 0.16 & - & - \\
\hline Total nonessential & 21.56 & 34.7 & 54.3 \\
\hline Total amino acids & 66.44 & 87.15 & 88.2 \\
\hline
\end{tabular}




\section{Role of Saccharomyces cerevisiae in animals feed}

Saccharomyces cerevisiae is one of the microbes that have been implicated on food safety. ${ }^{13,48}$ Saccharomyces cerevisiae is not only useful in human diets but also in animal feed. As such it also has useful role in animal diets . ${ }^{56-58}$ Llopis et al. ${ }^{59}$ reported that Saccharomyces cerevisiae are essential for good health because of its intrinsic nutritional quality and bio-functional characteristics. Probably due to these, it has been widely studied in animal especially domesticated ones such as cattle, goats, sheep etc, and other livestock's such as poultry (birds). Stercova et al. ${ }^{60}$ reported that live cultures of Saccharomyces cerevisiae on animal diet could enhance the role of beneficial digestive microflora and suppress the growth of pathogens, thereby contributing to the improvement of performance. This section highlights the specific roles of Saccharomyces cerevisiae in animal diets, growth and productivity.

\section{Nutrient digestibility}

Saccharomyces cerevisiae have been variously reported to play essential role in nutrient digestibility in animals. Abd El-Tabawab et al. ${ }^{61}$ reported that probiotics improves nutrient digestibility and feed conversion rate among ruminant animals. Stercova et al. ${ }^{60}$ studied the role of live Saccharomyces cerevisiae on nutrient digestibility and fecal microflora using dogs as experimental animal and reported an improvement in the neutral detergent fiber. Khadem et al. ${ }^{62}$ studied the effects of live yeast Saccharomyces cerevisiae (strain Sc 47) on rumen fermentation, microbial populations, nutrient, digestibility, alfalfa degradability and performances of sheep and results showed that $2.5 \mathrm{~g}$ of organisms per sheep/day could enhance ruminal fermentation and superior performances in Chall sheep. According to Sontakke ${ }^{49}$ , live yeast in diet of ruminant animals could enhance digestibility and absorption of minerals (viz: phosphorus, magnesium, calcium, copper, potassium, zinc and manganese), consumption of dry matter, utilization of fibre and other nutritive substances.

\section{Adsorption of toxic metal}

Heavy metals are known to be toxic at certain concentration for the essential ones, while the non-essential metals are highly toxic even at low concentrations. ${ }^{63-67}$ Microbes such as Saccharomyces cerevisiae have the tendency to remove heavy metals through biosorption. ${ }^{20}$ Furthermore, El-Moneim et al. ${ }^{68}$ reported that Saccharomyces cerevisiae is a strong probiotic agent that could detoxify cadmium in food, thereby reducing the harmful effect of its toxicity in animal diets.

\section{Weaning potentials}

Weaning is one of the most important stress periods in pig farming industry, and it deeply affects gut health and the immune system. ${ }^{69}$ The authors further reported that weaning could result in the decline feed intake among ruminant animal such as piglets that have serious health effects such as diarrhea and dysfunction of the immune system. Trckova et al. ${ }^{57}$ reported that dietary supplementation with live Saccharomyces cerevisiae in diets of sows and piglets in the late gestation, suckling, and postweaning periods could lead to reduction in the duration and severity of postweaning diarrhea caused by enterotoxigenic Escherichia coli. Abd El-Tabawab et al. ${ }^{61}$ reported that Saccharomyces cerevisiae in ruminant could lead to reduction in neonatal diarrhea and mortality. Bruno et al. ${ }^{58}$ reported that dairy cow diets supplemented with yeast culture enhance lactation performance by increasing yields of milk when exposed to heat stress condition.

\section{Milk production}

According to $\mathrm{Al}$ - Jassem et $\mathrm{al}^{70}{ }^{7}$, milk is an essential nutrient that contains several vital nutrients required for growth. Typically, the udder is one of the vital areas in ruminant that are affected by infection. Therefore, milk production is influenced by infection level. Dead bacteria could cause toxin that predispose the ruminant animals to inflammation of the udder. But several microbes such as Saccharomyces cerevisiae play essential role in milk production among ruminant animals. AbdEl-Tabawab et al. ${ }^{61}$ stated that Saccharomyces cerevisiae enhance milk production in ruminant animals. Al - Jassem et al. ${ }^{70}$ reported that Saccharomyces cerevisiae could boost milk production in Crossbred Holstein Cows. Zhu et al. ${ }^{71}$ also reported that Saccharomyces cerevisiae in cow diet could aid in the effective maintenance of milk during mid-lactation period. Yalçın et al. ${ }^{72}$ reported that live Saccharomyces cerevisiae can improve the nutritional value, milk production and its quality in cow.

\section{Performance}

The use of probiotics has showed to confer and improve productivity/performance. ${ }^{61}$ Several substrates have demonstrated potential for utilization in animal feed. Some of them have reported to boost performance in livestock's. Liu et al.$^{69}$ reported Saccharomyces cerevisiae cell wall extract supplemented to feed could improve growth performance, concentration of some essential amino acids, and alleviate oxidative stress in weaning piglets. Kiros et al. $^{73}$ reported that live Saccharomyces cerevisiae could boost performance and hindgut microbiota composition (especially Coriobacteriaceae, Ruminococcaceae, Clostridiaceae, Peptostreptococcaceae, and Peptococcaceae) of weaning pigs. Scott et al. ${ }^{74}$ reported that Saccharomyces cerevisiae in diets of heifers could improve growth performance, carcass characteristics, and reduce liver abscess. Aghdamshahriar et al. ${ }^{75}$ reported that Saccharomyces cerevisiae in fish meal and poultry by-product protein can enhance performance in broilers and its meat quality.

\section{Immunity}

Animals general possess a primitive defense against the pathogens that they may be susceptible to. Most animals have innate or natural immunity that help them wade off some diseases causing pathogens. On the other hand, some microbes have the tendency to protect an animal against low immunity. Specifically, Saccharomyces cerevisiae has the tendency to confer immunity in ruminant animals. ${ }^{61}$ Luquetti et al. ${ }^{76}$ reported that $0.2 \%$ supplementation of Saccharomyces cerevisiae in cell wall is capable of protecting the intestinal mucosa of broiler chickens vaccinated against coccidiosis.

\section{Rumen maturity and stabilization}

With the restriction in the use of antibiotics in livestock, studies in the use of botanicals and microbes as additives in feed have increased. The use of probiotics has showed to enhance rumen microbial ecosystem and good health among animals. ${ }^{61}$ Several factors lead to imbalance in flora population in young ruminant animals and they are more prone to infection. Several microbes play essential role in rumen of ruminant animals. Sontakke ${ }^{49}$ reported that Saccharomyces cerevisiae enhance the population and stability of cellulolytic rumen microbes. Kowalik et al. ${ }^{77}$ reported that Saccharomyces cerevisiae in diet of heifer increase rumen fluid $\mathrm{pH}$, molar concentration of acetate and acetate to propionate ratio, but decrease molar proportions 
of propionate and butyrate, total protein, triacylglycerol and total cholesterol concentrations. Zhu et al. ${ }^{71}$ reported that Saccharomyces cerevisiae fermentation products (corn stover) improved cow rumen function causing the microbial density to shift toward greater rumen fermentation efficiency which is characterized by high rumen fungi and cellulolytic bacteria and low lactate producing bacteria; production of high energy and protein which are indicated by greater ruminal volatile fatty acid concentration; and an enhanced nitrogen conversion. Doležalet al. ${ }^{56}$ reported that Saccharomyces cerevisiae (SC-47) has positive effect on ruminal digestion in dairy cows of Holstein breed especially with regard to $\mathrm{pH}$ and volatile fatty acids. Authors have also reported that Saccharomyces cerevisiae are known to stabilize the $\mathrm{pH}$ of the rumen. ${ }^{49,61}$

\section{Fiber degradation}

Yeast species including Saccharomyces cerevisiae that are used as probiotic has the tendency to enhance the growth and activities of fibre-degrading microorganisms. ${ }^{49}$ Typically, rumen of animals can be considered as anaerobic condition but dissolved oxygen can be traced to the rumen through feed and water intake as well as salivation. ${ }^{49} \mathrm{As}$ such, yeast cell have the tendency to scavenge for oxygen. ${ }^{49}$ Cömert et al. $^{78}$ reported Saccharomyces cerevisiae supplementation and anhydrous ammonia treatment of wheat straw improves degradability, weight gain etc.

\section{Conclusion and the way forward}

Palm oil and cassava mill effluents cause an alteration in receiving environment (soil and surface water). Studies have shown that microbes such as Saccharomyces cerevisiae has the tendency to reduce the pollution associated with both effluents while generating biomass. The biomass generated from both effluents is of low yield which is approximately $4.00 \mathrm{~g} / \mathrm{L}$. The biomass cultured in both effluents has shown to contain appreciable amount of protein and essential amino acid. Specifically, Saccharomyces cerevisiae biomass grown in cassava mill effluents contains some essential heavy metals, low in cyanide and appreciable amount of cations (calcium, magnesium, sodium and potassium). Hence, utilization of both effluents to grow Saccharomyces cerevisiae biomass for possible use in animal feed industry will reduce the attendant environmental impacts associated with the effluents while minimizing cost of conventional feeds. Due to the potentials of Saccharomyces cerevisiae biomass from both effluents to be utilized in animal feed, there is the need for research to focus on techniques through which the biomass produced could be enhanced. Evaluation of other nutrient determinant such as vitamins, and possiblely assessing the effectiveness of the biomass in animal diets with regard to digestibility, milk production, immunity conferment, rumen microflora and $\mathrm{pH}$ stabilization, overall performance etc.

\section{Acknowledgments}

The abstract of this study was presented in $5^{\text {th }}$ Annual Nigerian Society for Microbiology south east zonal symposium. Themed Microbiological Applications for National Economic Development held in Federal polytechnic Nekede, Nigeria between 24-25 May 2018 .

\section{Conflict of interest}

The author declares there is no conflict of interest.

\section{References}

1. Izah SC, Ohimain EI. The challenge of biodiesel production from oil palm feedstock's in Nigeria. Greener Journal of Biological Science. 2013;3(1):1-12.

2. Izah SC, Ohimain EI. Microbiological quality of crude palm oil produced by smallholder processors in the Niger Delta, Nigeria. Journal of Microbiology and Biotechnology Research. 2013;3(2):30-36.

3. Izah SC, Ohimain EI. Microbiological quality of palm oil used in Nigeria: Health impacts perspective. Point Journal of Botany and Microbiology Research. 2016;2(1):037-045.

4. Izah SC, Ohimain EI. The opportunities and weakness of Nigerian oil palm industry. Biotechnological Research. 2016;2(1):33-43.

5. Ohimain EI, Oyedeji AA, Izah SC. Employment effects of smallholder oil palm processing plants in Elele, Rivers State, Nigeria. International Journal of Applied Research and Technology. 2012;1(6):83-93.

6. Izah SC, Ohimain EI, Obieze FAU. Material-mass balance of smallholder oil palm processing in the Niger Delta, Nigeria. Advance Journal of Food Science and Technology. 2013;5(3):289-294.

7. Ohimain EI, Emeti CI, Izah SC, et al. Small scale palm oil business in Nigeria; a feasibility study. Greener Journal of Business and Management Studies. 2014;4(3):070-082.

8. Ohimain EI, Emeti CI, Izah SC. Employment and socioeconomic effects of semi-mechanized palm oil mill in Bayelsa state, Nigeria Asian Journal of Agricultural Extension, Economics and Sociology. 2014;3(3):206-216.

9. Zhang M, Xie L, Yin Z, et al. Biorefinery approach for cassava-based industrial wastes: Current status and opportunities. Bioresource Technology. 2016;215:50-62.

10. Ohimain EI, Izah SC. Energy self-sufficiency of smallholder oil palm processing in Nigeria. Renewable Energy. 2014;63:426-431.

11. Ohimain EI, Izah SC, Abah SO. Air quality impacts of smallholder oil palm processing in Nigeria. Journal of Environmental Protection. 2013;4:83-98.

12. Izah SC. Possible Challenges of potential drivers of oil palm processing sector in Nigeria. Journal of Biotechnology Research. 2016; 2(10):73-79.

13. Izah SC, Bassey SE, Ohimain EI. Assessment of heavy metal in cassava mill effluent contaminated soil in a rural community in the Niger Delta region of Nigeria. EC Pharmacology and Toxicology.2017;4(5):186-201.

14. Izah SC, Bassey SE, Ohimain EI. Geo-accumulation index, enrichment factor and quantification of contamination of heavy metals in soil receiving cassava mill effluents in a rural community in the Niger Delta region of Nigeria. Molecular Soil Biology. 2017;8(2):7-20.

15. Izah SC, Bassey SE, Ohimain EI. Assessment of pollution load indices of heavy metals in cassava mill effluents contaminated soil: a case study of small-scale cassava processing mills in a rural community of the Niger Delta region of Nigeria. Bioscience Methods. 2017;8(1):1-17.

16. Izah SC, Bassey SE, Ohimain EI. Changes in the treatment of some physico-chemical properties of cassava mill effluents using Saccharomyces cerevisiae. Toxic. 2017;5(4).

17. Izah SC, Bassey SE, Ohimain EI. Removal of Heavy Metals in Cassava Mill Effluents with Saccharomyces cerevisiae isolated from Palm Wine. MOJ Toxicology. 2017;3(4):00057.

18. Izah SC, Bassey SE, Ohimain EI. Cyanide and Macro-Nutrients Content of Saccharomyces cerevisiae Biomass Cultured in Cassava Mill Effluents. International Journal of Microbiology and Biotechnology. 2017;2(4):176-180. 
19. Izah SC, Bassey SE, Ohimain EI. Amino acid and proximate composition of Saccharomyces cerevisiae biomass cultivated in Cassava mill effluents. Molecular Microbiology Research. 2017;7(3):20-29.

20. Izah SC, Bassey SE, Ohimain EI. Assessment of Some Selected Heavy Metals in Saccharomyces cerevisiae Biomass Produced from Cassava Mill Effluents. EC Microbiology. 2017;12(5):213-223.

21. Izah SC, Bassey SE, Ohimain EI. Impacts of Cassava mill effleunts in Nigeria. Journal of Plant and Animal Ecology. 2018;1(1):14- 42.

22. Izah SC, Bassey SE, Ohimain EI. Ecological risk assessment of heavy metals in cassava mill effluents contaminated soil in a rural community in the Niger Delta Region of Nigeria. Molecular Soil Biology. 2018;9(1):1-11.

23. Izah SC. Estimation of Saccharomyces cerevisiae Biomass Cultured in Cassava Mill Effluents. Environmental Analysis and Ecology Studies. 2018;2(5).

24. Izah SC. Estimation of Potential Cassava Mill Effluents Discharged into Nigerian Environment. Environmental Analysis and Ecology Studies. 2018;2(5). EAES.000550.2018. DOI: 10.31031/EAES.2018.02.000550

25. Izah SC, Ohimain EI. Bioethanol production from cassava mill effluents supplemented with solid agricultural residues using bakers' yeast (Saccharomyces cerevisiae). Journal of Environmental Treatment Techniques. 2015;3(1):47-54.

26. Ohimain EI, Izah SC. Possible contributions of palm oil mill effluents to greenhouse gas emissions in Nigeria. British Journal of Applied Science and Technology. 2014;4(33):4705-4720.

27. Ohimain EI, Izah SC. Estimation of potential electrical energy and currency equivalent from un-tapped palm oil mill effluents in Nigeria. International Journal of Farming and Allied Science. 2014;3(8):855-862.

28. Ohimain EI, Izah SC. Potential of Biogas Production from Palm Oil Mills' Effluent in Nigeria. Sky Journal of Soil Science and Environmental Management. 2014;3(5):50-58.

29. Ohimain EI, Izah SC. A review of biogas production from palm oil mill effluents using different configurations of bioreactors. Renewable \& Sustainable Energy Reviews.2017;70:242-253.

30. Ohimain EI, Daokoru-Olukole C, Izah SC, et al. Microbiology of palm oil mill effluents. Journal of Microbiology and Biotechnology Research. 2012;2(6):852-857.

31. Ohimain EI, Seiyaboh EI, Izah SC, et al. Some selected physico-chemical and heavy metal properties of palm oil mill effluents. Greener Journal of Physical Sciences. 2012;2(4):131-137.

32. Ohimain EI, Izah SC. Water minimization and optimization by smallscale palm oil mill in Niger Delta, Nigeria. Journal of Water Research. 2013;135:190-198.

33. Awotoye OO, Dada AC, Arawomo GAO. Impact of Palm Oil Processing Effluent Discharging on the Quality of Receiving Soil and Rivers in South Western Nigeria. Journal of Applied Sciences Research 2011;7(2):111-118.

34. Singh RP, Ibrahim MH, Norizan E, et al. Composting of waste from palm oil mill: a sustainable waste management practice. Rev. Environ $\mathrm{Sci}$ Biotechnol. 2010;9(4):331-344.

35. Okwute LO, Isu NR. The environmental impacts of palm oil mill effluent (POME) on some physico-chemical parameters and total aerobic bioload of soil at a dump site in Anyigba, Kogi State, Nigeria. African Journal of Agricultural Research. 2007;2(12):656-662.

36. Izah SC, Angaye TCN, Ohimain EI. Environmental Impacts of Oil palm processing in Nigeria. Biotechnological Research. 2016;2(3):132-141.

37. Ohimain EI, Silas-Olu DI, Zipamoh JT. Biowastes generation by small scale cassava processing centres in Wilberforce Island, Bayelsa State, Nigeria. Greener Journal of Environmental Management and Public Safety. 2013;2(1):51-59.
38. Izah SC, Aigberua AO. Assessment of microbial quality of cassava mill effluents contaminated soil in a rural community in the Niger Delta, Nigeria. EC Microbiology. 2017;13(4):132-140.

39. Enerijiofi KE, Bassey ES, Fagbohun GJ. Assessment of the impact of cassava mill effluent (CME) on the Microbial diversity, physicochemical parameters and heavy Metal concentrations in the receiving soil. Ife Journal of Science. 2017;19(2):399-407.

40. Adeyemo OK. Haematological and histopathological effects of cassava mill effluent in Clarias gariepinus. African Journal of Biomedical Research. 2005;8(3):179-183

41. Asogwa CN, Ezenwajiaku FO, Okolo CA, et al. Behavioural and biochemical responses of juvenile catfish (Clarias gariepinus) exposed to graded concentrations of cassava waste water. Animal Research International. 2015;12(1):2136-2142.

42. Otunne RN, Kinako PDS. Effects of cassava effluent on Egbema denizens: a case of Mmahu community in Egbema. Intern J Res Develop. $1-5$.

43. Olorunfemi DI, Lolodi O. Effect of cassava processing effluents on antioxidant enzyme activities in Allium cepa L. Biokemistri. 2011;23(2):49-61.

44. Nwakaudu MS, Kamen FL, Afube G, et al. Impact of cassava processing effluent on agricultural soil: a case study of maize growth. J Emerging Trends in Eng Appl Sci. 2012;3(5):881-885.

45. Orhue ER, Imasuen EE, Okunima DE. Effect of Cassava mill effluent on some soil chemical properties and the growth of fluted pumpkin (Telfairia occidentalis Hook F.). Journal of Applied and Natural Science. 2014;6(2):320-325.

46. Broadway PR, Carroll JA, Sanchez NCB. Live yeast and yeast cell wall supplements enhance immune function and performance in foodproducing livestock: a review. Microorganisms. 2015;3:417-427.

47. Iwuagwu JO, Ugwuanyi JO. Treatment and valorization of palm oil mill effluent through production of food grade yeast biomass. Journal of Waste Management. 2014:1-9.

48. Izah SC. Potentials of yeast biomass production from food processing wastes effluents. EC Nutrition. 2017;8(3):72-74.

49. Sontakke U. Benefits of Saccharomyces cerevisiae as a feed additive in ruminants. 2012.

50. Suarez C, Guevara CA. Probiotic use of yeast Saccharomyces cerevisiae in animal feed. Res $J$ Zool. 2018; 1(1).

51. Onofre SB, Bertoldo IC, Abatti D, et al. Chemical composition of the biomass of saccharomyces cerevisiae - (meyen ex e. c. hansen, 1883) yeast obtained from the beer manufacturing process. International Journal of Environment, Agriculture and Biotechnology. 2017;2(2):558562.

52. Onyeulor PN, Nwaehiri LU. The use of fermented potato peels as an alternative to protein source. In: microbiological applications for national economic development. $5^{\text {th }}$ Annual Nigerian Society for Microbiology south east zonal symposium held in Federal polytechnic Nekede, Nigeria. 2018.

53. Aruna TE, Aworh OC, Raji AO, et al. Protein enrichment of yam peels by fermentation with Saccharomyces cerevisiae (BY4743). Annals of Agricultural Science. 2017; 62(1):33-37.

54. FAO/WHO. Protein quality evaluation," Report of the Joint FAO/WHO Expert Consultation. FAO Food and Nutrition Paper 51, Food and Agriculture Organization of the United Nations, Rome, Italy. 1991.

55. Ogbonda $\mathrm{KH}$, Aminigo RE, Abu GO. Influence of temperature and $\mathrm{pH}$ on biomass production and protein biosynthesis in a putative Spirulina sp. Bioresource Technology. 2007;98(11):2207-2211.

56. Doležal P, Doležal J, Třináctý J. The effect of Saccharomyces cerevisiae on ruminal fermentation in dairy cows. Czech Journal of Animal Science. 2005;50(11):503-510. 
57. Trckova M, Faldyna M, Alexa P, et al. The effects of live yeast Saccharomyces cerevisiae on postweaning diarrhea, immune response, and growth performance in weaned piglets. Journal of Animal Science. 2014;92(2):767-774.

58. Bruno RGS, Rutigliano HM, Cerri RL, et al. Effect of feeding Saccharomyces cerevisiae on performance of dairy cows during summer heat stress. Animal Feed Science and Technology. 2009;150(3-4):175186 .

59. Llopis S, Hernández-Haro C, Monteoliva L, et al. Pathogenic potential of Saccharomyces strains isolated from dietary supplements. PLOS ONE. 2014;9(5):e98094.

60. Stercova E, Kumprechtova D, Auclair E, et al. Effects of live yeast dietary supplementation on nutrient digestibility and fecal microflora in beagle dogs. J Anim Sci. 2016;94(7):2909-2918.

61. Abd El Tawab MM, Youssef IMI, Bakr HA, et al. Role of probiotics in nutrition and health of small ruminants. Pol J Vet Sci. 2016;19(4):893906

62. Khadem AA, Pahlavan M, Afzalzadeh A, et al. Effects of live yeast Saccharomyces cerevisiae on fermentation parameters and microbial populations of rumen, total tract digestibility of diet nutrients and on the in situ degradability of alfalfa hay in Iranian chall sheep. Pak J Biol Sci. 2007;10(4):590-597.

63. Izah SC, Chakrabarty N, Srivastav AL. A review on heavy metal concentration in potable water sources in nigeria: human health effects and mitigating measures. Exposure and Health. 2016;8(2):285-304.

64. Izah SC, Srivastav AL. Level of arsenic in potable water sources in Nigeria and their potential health impacts: A review. Journal of Environmental Treatment Techniques. 2015;3(1):15-24

65. Izah SC, Ineyougha ER. A review of the microbial quality of potable water sources in Nigeria. Journal of Advances in Biological and Basic Research. 2015;1(1):12-19.

66. Aigberua AO, Izah SC, Isaac IU. Level and health risk assessment of heavy metals in selected seasonings and culinary condiments used in Nigeria. Biological Evidence. 2018;8(2):6-15.

67. Izah SC, Aigberua AO. Comparative Assessment of selected heavy metals in some common edible vegetables sold in Yenagoa metropolis, Nigeria. Journal of Biotechnology Research. 2017;3(8):66-71.

68. Abd-El-Moneim OM, Abd El-Kader HA, Abd El-Rahim AH, et al. Modulatory role of Saccharomyces cerevisiae against cadmium-induced genotoxicity in mice. J Arab Soc Med Res. 2017;12:27-38.
69. Liu G, Yu L, Martínez Y, et al. Dietary Saccharomyces cerevisiae cell wall extract supplementation alleviates oxidative stress and modulates serum amino acids profiles in weaned piglets. Oxid Med Cell Longev. 2017.

70. Al-Jassem AF, Yousef MY, Abid Al-Mayahi MAA. Effect of different levels of bread yeast Saccharomyces cerevisiae in the production of milk and its components for crossbred holstein cows (1) production of milk and the components and quantity of feed consumed. Int. J. Pure App. Biosci. 2017;5(6):19-26.

71. Zhu W, Wei Z, Xu N, et al. Effects of Saccharomyces cerevisiae fermentation products on performance and rumen fermentation and microbiota in dairy cows fed a diet containing low quality forage. J Anim Sci Biotechnol. 2017;8:36.

72. Yalçın S, Can P, et al. The nutritive value of live yeast culture (saccharomyces cerevisiae) and its effect on milk yield, milk composition and some blood parameters of dairy cows. Asian-Aust. J. Anim. Sci. 2011;24(10):1377-1385.

73. Kiros TG, Derakhshani H, Pinloche E, et al. Effect of live yeast Saccharomyces cerevisiae (Actisaf Sc 47) supplementation on the performance and hindgut microbiota composition of weanling pigs. Scientific Reports. 2018;8:5315.

74. Scott MF, Dorton PASKL, Henry DL, et al. Effects of feeding a Saccharomyces cerevisiae fermentation prototype on performance, carcass characteristics, and liver abscess prevalence of beef heifers at a commercial feedlot. The Professional Animal Scientist. 2016;33(3):320 326.

75. Aghdamshahriar H, Nazer-Adl K, Ahmadzadeh AR. The effect of yeast (Saccharomyces cerevisiae) in replacement with fish meal and poultry by-product protein in broiler diets.

76. Luquetti BC, Furlan RL, Alarcon MFF, et al. Supplementation on the performance and intestinal mucosa development and integrity of broiler chickens vaccinated against coccidiosis. Brazilian Journal of Poultry Science. 2012;14(2):89-95

77. Kowalik B, Skomiał J, Pajak JJ, et al. Population of ciliates, rumen fermentation indicators and biochemical parameters of blood serum in heifers fed diets supplemented with yeast (Saccharomyces cerevisiae) preparation. Animal Science Papers and Reports. 2012;30(4):329-338.

78. Cömert M, Şayan Y, Özelçam H, et al. Effects of Saccharomyces cerevisiae supplementation and anhydrous ammonia treatment of wheat straw on in-situ degradability and, rumen fermentation and growth performance of yearling lambs. Asian-Australas J Anim Sci. 2015;28(5):639-646 